\title{
ASSESSMENT OF A HEALTHY LIFESTYLE AND QUALITY OF LIFE OF MEN AND WOMEN IN MODERN SOCIETY BASED ON SF-36
}

\author{
Tatiana Krutsevich ${ }^{\mathrm{ABCD}}$, Sergii Trachuk ${ }^{1 \mathrm{ABCD}}$, Oksana Ivanik ${ }^{1 \mathrm{ABCD}}$, \\ Natalia Panhelova ${ }^{2 A B C D}$, Mariia Brychuk ${ }^{1 \mathrm{ABCD}}$, Halyna Kedrych ${ }^{3 \mathrm{ABCD}}$ \\ ${ }^{1}$ National University of Ukraine on Physical Education and Sport \\ ${ }^{2}$ Hryhorii Skovoroda University in Pereiaslav \\ ${ }^{3}$ Taras Shevchenko Regional Humanitarian Pedagogical Academy in Kremenets \\ Authors' Contribution: A - Study design; B - Data collection; C - Statistical analysis; D - Manuscript Preparation; E - Funds Collection
}

Corresponding Author: Sergii Trachuk, E-mail: trachuk_sergey@i.ua

Accepted for Publication: August 12, 2021

Published: September 25, 2021

DOI: 10.17309/tmfv.2021.3.04

\begin{abstract}
Quality of life (QL) is defined as the subjective perception of one's own well-being in a socio-cultural context, the satisfaction of one's desires and the achievement of an ideal level of well-being. Quality of life is related to health (HRQOL), refers to the functioning and well-being in the physical, mental and social dimensions of life.

Research purpose: to analyze the main factors of quality of life of male and female population in modern Ukrainian society.

Material and Methods. 482 men and women aged 20-60 took part in sociological research.

The following research methods were used to solve the problemsset in the work: analysis and processing of special literature and data from the Internet; pedagogical observation; questionnaires (SF-36); methods of mathematical statistics.

Results. The results of their own research show that the male population had a better quality of life on all scales of the SF-36 questionnaire compared to women $(\mathrm{p}<0.05)$. Respondents under the age of 20-29 had indicators of quality of life above average on the scales of physical and role physical functioning; pain in this age group did not have a significant impact on quality of life. The general state of health was assessed above the average level by respondents aged 20-29 and 30-39, regardless of gender, they were characterized by high scales of social activity and viability. Conclusions. It is established that the indicator General health is a system-forming factor of quality of life for men and women in terms of the number of correlations. The obtained results allowed to determine the expediency and speed of implementation of preventive measures for men and women depending on the content of certain scales. Decreased overall health $(\mathrm{GH})$ in men and women after the age of 50 significantly affects their quality of life, as evidenced by the large number of significant correlation coefficients. In women over 50 years of age, there is a sharp decrease in RP (role functioning due to physical condition) to 46 points, vital activity (VT) to 50 points, role functioning (due to emotional state) (RE) to 53 points. In men at this age, role functioning increases to 90 points, and social functioning (SF) to 89 points, which may indicate an uneven distribution of family and social functions in the lives of people of different sexes, overloading women with household chores, which prevents them from spending free time, affects the emotional state.

Keywords: quality of life, lifestyle, physical activity, health, adults.
\end{abstract}

\section{Introduction}

Quality of life (QOL) is defined either as a subjective perception of one's own well-being in a socio-cultural context, the satisfaction of one's desires and the achievement

(C) Krutsevich, T., Trachuk, S., Ivanik, O., Panhelova, N., Brychuk, M., Kedrych, H., 2021. of an ideal level of well-being. Quality of life is related to health (HRQOL), refers to the functioning and well-being in the physical, mental and social dimensions of life (Ware \& Sherbourne,1992; Brazier, 1993; Wassertheil-Smoller \& Smoller, 2015).

The world community of scientists concludes that there is a relationship between well-being, quality of life and ob- 
jective health indicators at the level of quadratic correlation coefficients equal to 0.14 , and then health affects well-being, and subjective well-being affects to prolong life by $7-10$ years (WHO, 2007; 2013; 2018).

When it comes to human well-being, it is often associated with economic well-being and only then pay attention to quality of life and health (Hardman \& Stensel, 2003; Cavill, Kahlmeier, \& Racioppi, 2006; Krutsevich \& Bezverhnia, 2010).

In countries where the majority of the population feels disadvantaged and disenfranchised, there are disproportionately poor outcomes both in terms of health and other social determinants. Of great importance is the systematic assessment of the health effects of rapidly changing environmental conditions, especially the effects of technology, working conditions, energy production and urbanization, and this assessment should include actions to achieve health benefits (Lee, Shiroma, Lobelo, Puska, Blair, Katzmarzyk, 2012; World Health Organization 2013; Imas, Dutchak, \& Trachuk, 2013).

WHO defines quality of life as a person's perception of his life, including physical, mental and social well-being (WHO Quality of Life Assessment Group,1996).

Quality of life is always associated with health, although it is a complex characteristic of physical, psychological, emotional and social functioning of man, based on his subjective perception (Krutsevich, Imas, 2013).

Due to the extreme importance of the problem of the impact of lifestyle, physical activity on the duration and quality of life of the population of Ukraine, which, unfortunately, differs from the statistics of the European Union, it is necessary to determine the main factors of quality of life on the state of health and life expectancy.

The aim of our work is to identify in the population aspect the main factors of quality of life of male and female population in modern Ukrainian society.

\section{Material and method}

\section{Study participants}

482 men and women aged 20-60 took part in sociological research.

\section{Study organization}

The SF-36 Health Assessment Questionnaire is one of the most common methods for measuring health-related quality of life and is used to compare different populations (Brazier,1993; Ware, Kosinski, \& Keller, 1994; Brazier, Roberts, Deverill, 2002).

36 items of the questionnaire are grouped into eight scales: physical functioning, role activity, physical pain, general health, viability, social functioning. All scales form two components of psychological and physical well-being.

1. Physical Functioning (PF), reflects the degree of physical condition that limits the performance of physical activity (self-care, walking, climbing stairs, weight transfer, etc.).

2. Role-Physical Functioning (RP) - the influence of physical condition on daily role activities (work, performance of daily duties).

3. Bodily pain (BP) intensity and its effect on the ability to engage in daily activities, including housework and outof-home work.
4. General Health (GH) is a general assessment of your health.

5. Vitality (VT) means feeling full of strength and energy or, conversely, exhausted.

6. Social Functioning (SF) is defined by the degree to which a physical or emotional state limits social activity (communication).

7. Role-functioning due to emotional state (Role-Emotional - RE) involves assessing the extent to which the emotional state interferes with the performance of work or other daily activities (including large expenditures of time, reducing the amount of work, reducing its quality, etc.).

8. Mental Health $(\mathrm{MH})$ - characterizes the mood, the presence of depression, anxiety, a general indicator of positive emotions.

Each answer is evaluated in points. When forming a scale, these points are added and mathematically calculated by standard formulas. Scores on each scale can range from 0 to 100 , where 100 means complete health.

\section{Results}

The results of the analysis of responses of men and women in adulthood to the questionnaire SF-36 to determine the quality of life based on individual aggregate characteristics of the person in physical and mental terms at the time of completion of the questionnaire and during the last four weeks of life.

The questionnaire reflects the general well-being and the degree of satisfaction with those aspects of human life that are affected by health (Table 1).

For all scales, the Z-value was calculated in relation to the difference of the transformed value of each scale with its average value in the population to the standard deviation. When calculating the values used Z-values that correspond to the standards obtained for the US population (Brazier,1993).

Physical functioning, as an indicator that reflects the highest amount of daily physical activity in men $20-29$ years is at the level of 99 points, which indicates that physical activity is not limited to health, this can be seen on the general condition scale where the figure is above average and is 77 points, which may indicate certain interrelated predictors determining this condition.

In the group of men aged 20-29, there was a charitable influence of role functioning due to emotional state (100 points), which minimally limits the daily activity of men. However, all this against the background of possible depression, anxiety, disturbances, which is reflected in the indicator of the scale of mental health, which is 69 points. Perhaps all this is happening against the background of a high manifestation of social functioning (91 points), where communication, spending time with friends, neighbors and reflects the degree to which their physical and emotional state limits them.

A decrease in physical function to 71 points is observed in the age group of men 50 years and older. Tendencies to decrease are observed in the indicators of general condition (60 points), although the role of physical functioning according to the scale is equal to 90 points, which indicates that daily activities are not limited to the physical health of men 50 years and older. 
Table 1. Indicators of quality of life of men in the age plane SF-36, y.o

\begin{tabular}{|c|c|c|c|c|c|c|c|c|}
\hline \multirow[t]{2}{*}{ Quality of life scales for SF-36 } & \multicolumn{2}{|c|}{$\begin{array}{l}20-29 \\
n=60\end{array}$} & \multicolumn{2}{|c|}{$\begin{array}{l}30-39, \\
n=60\end{array}$} & \multicolumn{2}{|c|}{$\begin{array}{l}40-49, \\
n=64\end{array}$} & \multicolumn{2}{|c|}{$\begin{array}{c}50 \text { and more, } \\
n=60\end{array}$} \\
\hline & Mean & $\mathrm{Z}$ & Mean & $\mathrm{Z}$ & Mean & $\mathrm{Z}$ & Mean & $\mathrm{Z}$ \\
\hline Physical functioning $(\mathrm{PF})$ & 99 & 0.63 & 93 & 0.37 & 92 & 0.33 & 71 & -0.59 \\
\hline Role functioning (due to physical condition) (RP) & 81 & -0.01 & 83 & 0.05 & 80 & -0.04 & 90 & 0.26 \\
\hline Pain intensity $(\mathrm{BP})$ & 86 & 0.45 & 79 & 0.15 & 82 & 0.28 & 73 & -0.11 \\
\hline General condition $(\mathrm{GH})$ & 77 & 0.24 & 73 & 0.04 & 65 & -0.36 & 60 & -0.61 \\
\hline Vital activity (VT) & 71 & 0.48 & 63 & 0.09 & 65 & 0.19 & 61 & 0.00 \\
\hline Social functioning (SF) & 91 & 0.33 & 88 & 0.20 & 82 & -0.07 & 89 & 0.24 \\
\hline Role functioning (due to emotional state) (RE) & 100 & 0.57 & 82 & 0.02 & 84 & 0.08 & 67 & -0.43 \\
\hline Mental Health (MH) & 69 & -0.32 & 69 & -0.32 & 73 & -0.10 & 70 & -0.27 \\
\hline
\end{tabular}

Table 2. Indicators of quality of life of women in the age plane SF-36, points

\begin{tabular}{|c|c|c|c|c|c|c|c|c|}
\hline \multirow[t]{2}{*}{ Quality of life scales for SF-36 } & \multicolumn{2}{|c|}{$\begin{array}{l}20-29 \\
\mathrm{n}=66\end{array}$} & \multicolumn{2}{|c|}{$\begin{array}{l}30-39 \\
\mathrm{n}=52\end{array}$} & \multicolumn{2}{|c|}{$\begin{array}{l}40-49, \\
\mathrm{n}=60\end{array}$} & \multicolumn{2}{|c|}{$\begin{array}{c}50 \text { and more, } \\
n=60\end{array}$} \\
\hline & Mean & $\mathrm{Z}$ & Mean & $\mathrm{Z}$ & Mean & $\mathrm{Z}$ & Mean & $\mathrm{Z}$ \\
\hline Physical functioning (PF) & 91 & 0.28 & 91 & 0.28 & 82 & -0.11 & 73 & -0.50 \\
\hline Role functioning (due to physical condition) (RP) & 75 & -0.42 & 60 & -1.07 & 82 & -0.11 & 46 & -1.68 \\
\hline Pain intensity (BP) & 91 & 0.28 & 73 & -0.50 & 87 & 0.11 & 74 & -0.46 \\
\hline General condition $(\mathrm{GH})$ & 61 & -1.03 & 72 & -0.55 & 67 & -0.77 & 50 & -1.51 \\
\hline Vital activity (VT) & 61 & -1.03 & 63 & -0.94 & 69 & -0.68 & 50 & -1.51 \\
\hline Social functioning (SF) & 79 & -0.24 & 83 & -0.07 & 81 & -0.15 & 63 & -0.94 \\
\hline Role functioning (due to emotional state) (RE) & 78 & -0.28 & 87 & 0.11 & 78 & -0.28 & 53 & -1.38 \\
\hline Mental Health (MH) & 65 & -0.85 & 58 & -1.16 & 72 & -0.55 & 57 & -1.20 \\
\hline
\end{tabular}

In general, in the age groups of 30-39 years and 40-49 years there are similar downward trends, although with some heterochrony on certain scales.

The mental health rate of men of all ages is almost constant and is slightly above average, which coincides with men's responses to the Zapisochny's test, where more than $70 \%$ of men indicated that they live in a state of stress, but with age there is a slight tendency to increase the indicator, and men aged 20-39 years assess their mental health at 69 points, at $40-49$ years at 73 and after fifty at 70 points.

Indicators of women's quality of life need to be considered in detail by age, as the episodicity and inconsistency of data to increase or decrease by decades have been determined. It is possible that the wave-like changes in indicators are related to the traditional functions assigned to women, due to which they feel the burden of problems caused by the specifics of social roles and statuses (Table 2).

The only subjective indicator based on the results of the survey, which is stable at different ages, is physical functioning. In 20-39 years, women feel quite well, as evidenced by a high rate (91 points), in $40-49$ years and after 50 years, the rate decreases ( 82 points, 73 points).

Role functioning, which is largely due to physical condition in 20-29 years is 75 points, decreases in the age group of 30-39 years ( 60 points), at the age of $40-49$ years is a high level -82 points, and after 50 years is determined at the level of 46 points. Low scores on this scale previously indicate that daily activities and social position are significantly limited by the physical health of women 50 years and older.

The intensity of pain in women is quite high for all ages: 20-29 years (91 points), 30-39 years (73 points), 40-49 years (87 points), after fifty -74 points. Low values of the scale indicate that pain for physical reasons significantly limits the physical activity of women, in particular in the age groups: 30-39 years and 50 years and older.

The indicator of role functioning (due to emotional state) is above the scale in the age range of $20-29$ and $40-49$ years (equally 78 points), in the age group of $40-49$ years its value increases to 87 points, but after 50 years decreases to 53 points. This trend directly indicates the significant impact of emotional state, which interferes with and limits daily activities, in particular the performance of work or other normal daily activities, including the high cost of time to perform them, reducing the amount of work done, reducing its quality.

The tendency to increase the confidence of women in middle age can be traced in the indicator of social functioning, in women $20-29$ years it was 79 points, in the age group 30-39 years it increases to 83 points, in $40-49$ years is at 81 points. After the age of 50, women's social functioning decreases to 63 points, which means a significant restriction of social activity and social contacts, a decrease in the level of communication due to deteriorating health..

The indicator of the general condition determines the heterochronous curve of the obtained results with increase: in 20-29 years - 61 points, in 30-39 years -72 points, in $40-45$ years the indicator is 67 points and after 50 years -50 points.

Correlation analysis revealed that in all age groups of men and women, the highest number of probable correlations is observed between general health and other scales. (fig.1).

With a decrease in the indicator $(\mathrm{GH})$ in the age aspect, its influence on other indicators of quality of life increases.

In the age group of 20-29 years of men, there is a relationship between general health $(\mathrm{GH})$ and physical func- 


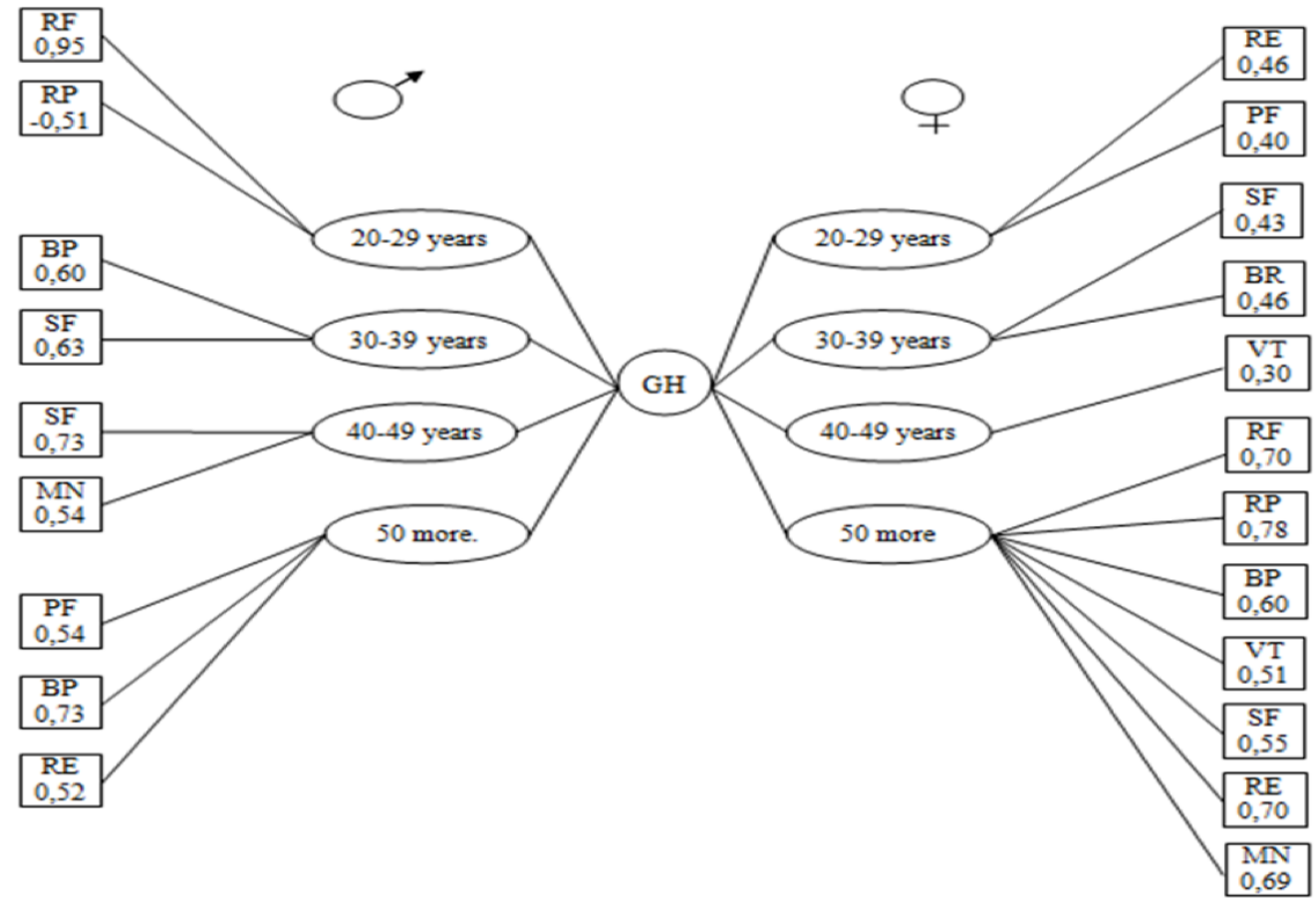

Fig.1. Correlation analysis of quality of life indicators of men and women

tioning $((\mathrm{PF}) \mathrm{r}=0.95)$ and feedback on role functioning due to physical condition $((\mathrm{RP}) \mathrm{r}=-0.51)$.

In men $30-39$ years of age, general health $(\mathrm{GH})$ is likely to correlate with pain intensity $((\mathrm{BP}) \mathrm{r}=0.60)$ and social functioning / activity (SF) $\mathrm{r}=0.63$.

In the group of men aged 40-49, it was found that general health $(\mathrm{GH})$ has even greater correlations with social functioning $((\mathrm{SF}) \mathrm{r}=0.73)$ and has an impact on mental health $((\mathrm{MH}) \mathrm{r}=0.55)$.

In the group of men aged 50-59, this indicator has the highest number of probable correlations: with physical functioning $(\mathrm{PF}) \mathrm{r}=0.54)$, pain intensity $((\mathrm{PI}) \mathrm{r}=0.73)$, emotional state $((\mathrm{ES}) \mathrm{r}=0.52)$.

In women aged 20-29, general health $(\mathrm{GH})$ is associated with emotional state $((\mathrm{ES}) \mathrm{r}=0.46)$ and physical functioning $((\mathrm{PF}) \mathrm{r}=0.40)$.

In women aged $30-39$ years, there is a correlation between general health $(\mathrm{GH})$ and social functioning (SF) $\mathrm{r}=0.43$ and pain intensity $(\mathrm{PI}) \mathrm{r}=0.46$.
In the age group of women 40-49 years, a weak relationship was found between general health $(\mathrm{GH})$ and vital activity ((VA) $\mathrm{r}=0.30)$.

With a decrease in general health $(\mathrm{GH})$ to 50 conventional units of women aged 50-59 have the highest number of probable correlations: with physical functioning (PF) $\mathrm{r}=0.70$ ), with role functioning due to physical condition $((\mathrm{PC}) \mathrm{r}=0.78)$, pain intensity $((\mathrm{PI}) \mathrm{r}=0.60)$, vital activity $((\mathrm{VA}) \mathrm{r}=0.51)$, social functioning $((\mathrm{SF}) \mathrm{r}=0.55)$, role functioning due to emotional state ((ES) $\mathrm{r}=0.70)$, mental health $((\mathrm{MH}) \mathrm{r}=0.69)$. This shows that the decline in general health significantly affects all indicators of quality of life of women over 50 years.

As can be seen in Fig.2, there are differences between the generalized indicators of quality of life, taking into account the age of men.

In all age groups, the quality of life is maintained at a stable high level, and the physical component of quality of life prevails over the psychological. However, in men 50 years

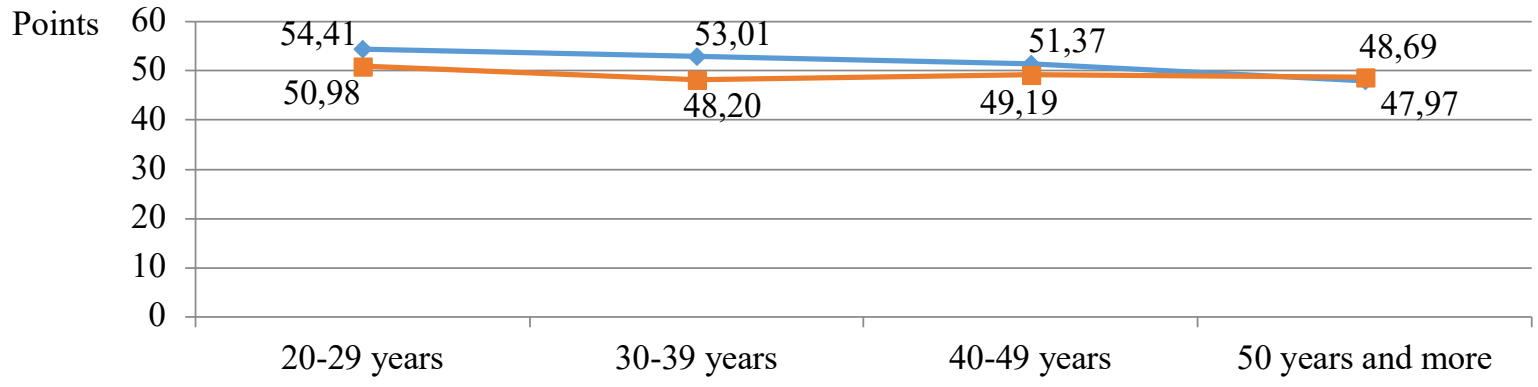

Fig. 2. Comparative rating of life quality of men considering age criteria 


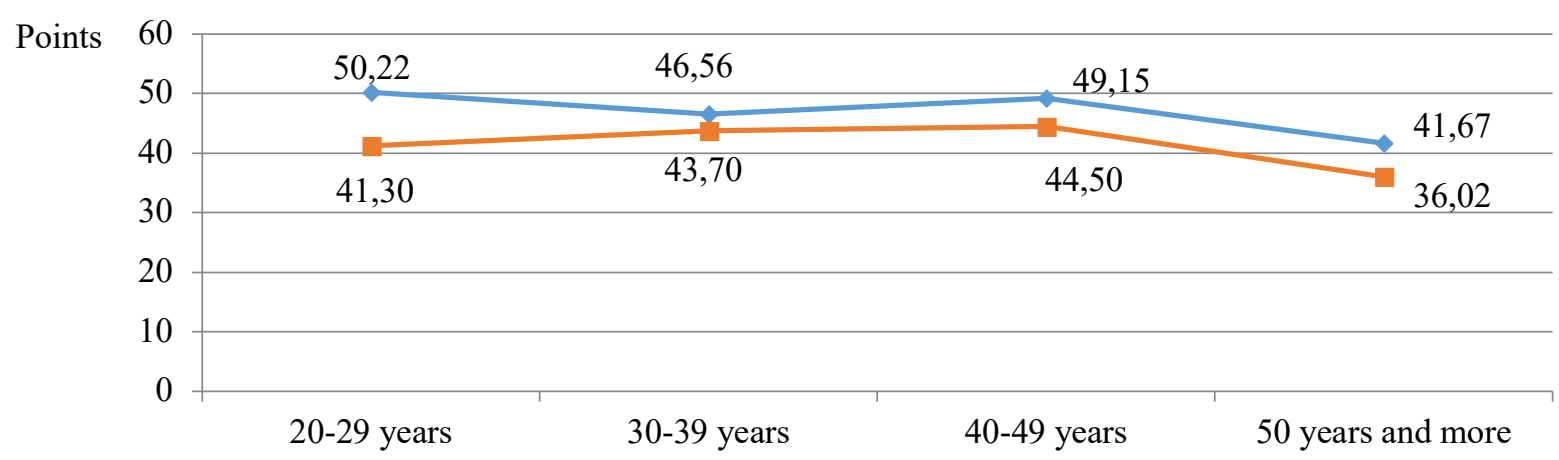

Fig. 3. Comparative rating of life quality of women considering age criteria

$\multimap$ Physical health component $(\mathrm{PH})$ $\neg$ Psycho health component (MH) and older, the psychological component of health slightly dominates over the physical component.

In women of all ages, quality of life in relation to the physical component of quality of life prevails over the psychological component of quality of life (fig.3).

The overall health and mental health scales of both women and men are steadily declining with age. Deterioration of quality of life, ie physical and emotional factors of a person, which were not at a high level, and are important for a person and affect him - deteriorate and increase the negative impact on overall health.

It is possible to allocate separately the indicator of vital activity at women which during a life does not rise above average value and makes 61 points in $20-29$ years, 63 points in 30-39 years, in 40-49 years grows to 69 points and after 50 makes 50 points.

The cardinal differences between men and women, the indicators of the SF-36 test, if we take into account the arithmetic mean, are observed in three scales - role functioning (due to physical condition), social functioning and role functioning (due to emotional state).

Thus, role functioning (due to physical condition) in men is 83.5 points, and in women 65.75 , which is noted on the components of quality of life. Role functioning (due to emotional state) on a certain scale is also much lower in women -74 points than in men -83.25 points. The indicator of social functioning is 10 units higher in men ( 85.5 points) than in women (76.5 points).

\section{Discussion}

The high level of quality of life on the one hand is the problem of ensuring a safe life for people, life without war, oppression, discrimination, material restrictions, bureaucratic manipulation of the human person. The key is the problem of organizing such a life, in which a significant place is given to relationships between people, where along with work that brings pleasure, a rational role is played by rationally organized leisure, active recreation for physical improvement and health, and pleasure and good mood (WHO, 2013, 2018).

Cavill, Kahlmeier, Racioppi (2006) called the cost-benefit ratio of healthy lifestyle programs as 1 to 8 . According to the World Health Organization, lack of proper physical activity leads to economic losses of 150-300 euros per person per year, which is directly correlated with quality life of the population (World Health Organization, 2007, 2008; World Health Organization Regional Office for Europe, 2013).

It is well known that leading a healthy lifestyle to maintain and promote health is five times more effective than medical and diagnostic procedures (Hallal, Andersen, Bull et alt., 2012; Gesell, Tesdahl, \& Ruchman, 2012; Health-Enhancing Physical Activity, 2013; Hotting \& Roder, 2013)

In Manual of physical activity for Americans (US Department of Health and Human Services, 2008; 2018) referring to the latest scientific data state that today about half of all American adults - 117 million people - have one or more chronic diseases preventable. However, almost 80 percent of adults do not meet the basic guidelines for aerobic and muscular activity. Lack of physical activity leads to $\$ 117$ billion in annual health care costs and about $10 \%$ of premature mortality.

At the same time, the WHO document (2018): «Global Action Plan on Physical Activity for 2018-2030: more active people for a healthier world», mentions a plan to increase physical activity by $15 \%$ among adults and adolescents by 2030 .

The WHO Global Plan of Action (2018) is defined with full awareness that countries are at different starting points in terms of efforts to increase physical activity and sedentary behavior. In addition, it recognizes that the priorities and preferences in relation to different types of physical activity in different conditions and in different population subgroups vary by culture, context and resources.

The established age features coincide with the data of previous sociological and scientific researches. According to research by foreign scientists, the contribution of various factors in maintaining good health is unequal. About $54 \%$ is a lifestyle in which negative factors / determinants play a significant role: unbalanced diet, smoking, lack of physical activity, excessive alcohol consumption (Cavill, Kahlmeier, \& Racioppi, 2006; Kirk-Sanchez \& McGough, 2014).

One of the most important indicators of health and well-being is life expectancy. Comparing WHO statistics for Ukraine and the EU, we note a difference in life expectancy of 10 years not in favor of Ukraine. The number of years of 
dysfunctional life, ie when a person begins to fight diseases, also attracts attention. In Europe, this figure is 9-11, and in Ukraine 11-13 years.

Krutsevich, Pangelova, Trachuk and Ivanik (2019) examining the place of physical activity in the quality of life of different age groups note the lack of its volume and noncompliance with modern recommendations. This factor in combination with negative lifestyle habits affects the indicators of physical, mental and social health, which leads to a decrease in the quality of life and reduce its duration in men and women in modern society.

In our studies, we found that the general health of groups of women 50-59 years has the highest number of probable correlations: with physical functioning; with role functioning due to physical condition; pain intensity; vital activity; social functioning; role functioning due to emotional state; mental health.

Massalsky (2015) examining the quality of life of the population in Germany using the SF-36 questionnaire, notes the importance of paired relationships for maintaining health as an important factor in quality of life for both men and women. The author suggests that the differences between men and women are related not only to differential psychophysiology, but also to the social pressure of gender roles.

Content analysis of the latest documents of the World Health Organization on the strategy in the field of physical activity for the European region (World Health Organization, 2008, 2010, 2013, 2018) and analyzed the components of quality of life using the SF-36 questionnaire, allowed to determine their leading components. Thus, we observe that life roles and inherent social stereotypes are clearly expressed in the nature of behavior depending on biological sex. There are bursts of vital activity and social functioning in the period of life when most women become professional.

Krutsevich, Imas (2013) in the study of types of employment in leisure time also note the characteristics that are inherent in men and women in the age aspect, but the general trends are clearly defined. Among the common and significant types of employment for men were watching TV (56\%), communicating with friends (37\%), housework (36\%), car repair $(28 \%)$, reading the press $(30.5 \%)$ and physical activity. (17\%). Among women, household chores (83\%), watching TV (46\%), reading fiction (46.5\%), communicating with friends $(47 \%)$, raising children $(44.5 \%)$, physical activity were singled out. (15.5\%).

Role functioning due to emotional or physical condition directly depends on biological sex because the roles that society assigns to men are considered more valuable than women.

\section{Conclusion}

General health $(\mathrm{GH})$ has been shown to be a systemic factor in the quality of life for males and females in terms of the number of correlations. The obtained results allowed to determine the feasibility and speed of implementation of preventive measures for men and women depending on the content of the defined scales. Decreased general health $(\mathrm{GH})$ in men and women over the age of 50 significantly affects their quality of life, as evidenced by the large number of significant correlation coefficients. In women over 50 years of age, there is a sharp decrease in RP (role functioning due to physical condition) to 46 points, vital activity (VA) to
50 points, role functioning (due to emotional state) (ES) to 53 points. In men at this age, role functioning increases to 90 points, and social functioning (SF) to 89 points, which may indicate an uneven distribution of family and social functions in the lives of people of different sexes, overloading women with household chores, which prevents them from actively spending free time, affects the emotional state.

It should be noted that all our researches were conducted before the Covid-19 pandemic, and in this aspect need additional research and analysis, because there have been many reformatts in the world.

\section{Conflict of interests}

The authors state that there is no conflict of interests.

\section{References}

Ware, J.E. Jr., \& Sherbourne, C.D. (1992). The MOS 36item short-form health survey (SF-36). I. Conceptual framework and item selection. Med Care, 30(6), 473-83. https://doi.org/10.1097/00005650-199206000-00002

Brazier, J. (1993). The SF-36 health survey questionnaire - a tool for economists. Health Econ., 2(3), 213-5. http://doi.org/10.1002/hec.4730020304

Wassertheil-Smoller, S., \& Smoller, J. (2015). Mostly about quality of life. Biostatistics and epidemiology, 163-70. https://doi.org/10.1007/978-1-4939-2134-8_7

World Health Organization (2007). Steps to health: a European framework to promote physical activity for health. Available from: http://www.euro.who.int/en/ health-topics/disease-prevention/physical-activity/ publications/2007/steps-to-health.-a-europeanframework-to-promote-physical-activity-for-health-2007

World Health Organization (2013). Health 2020. A European policy framework and strategy for the 21st century. Available from: http://www.euro.who.int/_data/assets/ pdf_file/0011/199532/Health2020-Long.pdf?ua=1

World Health Organization (2013). Strategy and action plan for healthy ageing in Europe, 2012-2020. Available from: http://www.euro.who.int/_data/assets/pdf_ file/0008/175544/RC62wd10Rev1-Eng.pdf

World Health Organization Regional Office for Europe (2013). Physical activity strategy for the WHO European Region 2016-2025. Available from: http://www.euro. who.int/_data/assets/pdf_file/0010/282961/65wd09e_ PhysicalActivityStrategy_150474.pdf

World Health Organization (2018). European health report 2018: More than numbers - evidence for all. Available from: http://www.euro.who.int/en/publications/abstracts/ european-health-report-2018.-more-than-numbersevidence-for-all-2018

World Health Organization (2018). Global action plan on physical activity 2018-2030. More active people for a healthier world. Geneva; Available from: https://apps.who. int/iris/bitstream/ha ndle/10665/272722/9789241514187eng.pdf

Hardman, A., \& Stensel, D. (2003). Physical activity and health: the evidence explained. London, Routledge. 
Cavill, Nick, Kahlmeier, Sonja, \& Racioppi, Francesca (2006). Physical activity and health in Europe: evidence for action. Copenhagen, WHO Regional Office for Europe.

Krutsevich, T., \& Bezverhnia, H. (2010). Rekreatsiya u fizychniy kulturi riznykh hrup naselennya. Kyev: Olympyiskaia lyteratura.

Lee, I.M., Shiroma, E.J., Lobelo, F., Puska, P., Blair, S.N., \& Katzmarzyk, P.T. (2012). Effect of physical inactivity on majornon-communicable diseases worldwide: an analysis of burden of disease and life expectancy. Lancet 380(9838), 219-229.

https://doi.org/10.1016/s0140-6736(12)61031-9

Imas, E., Dutchak, M., \& Trachuk, S. (2013). Stratehyy y rekomendatsyy po zdorovomu obrazu zhyzny y dvyhatelnoi aktyvnosty: sbornyk materyalov Vsemyrnoi orhanyzatsyy zdravookhranenyia. Kyev: Olympyiskaia lyteratura.

WHO Quality of Life Assessment Group. (1996). What quality of life? / The WHOQOL Group. World Health Forum, $17(4), 354-356$

Krutsevich, T., \& Imas, T. (2013). Tsennostnyye oriyentatsii lits zrelogo vozrasta v provedenii dosuga. Sportivniy visnik Pridnuprov'ya, 2, 5-11.

Ware, J.E., Kosinski, M., \& Keller, S.D. (1994). SF-36 Physical and Mental Health Summary Scales: A User's Manual. The Health Institute, New England Medical Center. Boston, Mass.

Brazier, J., Roberts, J., \& Deverill, M. (2002). The estimation of a preference-based measure of health from the SF-36. J Health Econ., 21(2), 271-92. https://doi.org/10.1016/s0167-6296(01)00130-8

World Health Organization (2008). A healthy city is an active city: a physical activity planning guide. Available from: http://www.euro.who.int/_data/assets/pdf_ file/0012/99975/E91883.pdf

Hallal, P.C., Andersen, L.B., Bull, F.C., Guthold, R., Haskell W., Ekelund, U. (2012). Global physical activity levels: surveillance, progress, pitfalls, and prospects. Lancet 380(9838), 247-257. https://doi.org/10.1016/S0140-6736(12)60646-1

Gesell, S., Tesdahl, E., \& Ruchman, E. (2012). The distribution of physical activity in an after-school friendship network. Pediatrics 129(6),106471. https://doi.org/10.1542/ peds.2011-2567

Health-Enhancing Physical Activity (2013). Council recommendation on promoting health-enhancing physical activity across sectors. Available from: https://ec.europa. eu/health/sites/health/files/nutrition_physical_activity/ docs/2013_hepa_en.pdf

Hotting, K., \& Roder, B. (2013). Beneficial effects of physical exercise on neuroplasticity and cognition. Neuroscience \&Biobehavioral Reviews. Neurosci Biobehav Rev, 37(9), 2243-2257. https://doi.org/10.1016/j.neubiorev.2013.04.005

Kirk-Sanchez, N.J., \& McGough, E.L. (2014). Physical exercise and cognitive performance in the elderly: current perspectives. Clin Interv Aging, 9, 51-62. https://doi. org/10.2147/CIA.S39506

Krutsevich, T., Pangelova, N., Trachuk, S., \& Ivanik, O. (2019). Motor activity of the male and female population in modern society. Journal of Physical Education and Sport, 19(3), 1591-1598. https://doi.org/10.7752/jpes.2019.03231

Massalskii R.I. (2015). Issledovanie kachestva zhizni naseleniia Germanii s pomoshchiu oprosnika SF-36. Sovremennye problemy nauki i obrazovaniia, 2-1

\title{
ОЦІНКА ЗДОРОВОГО СПОСОБУ І ЯКОСТІ ЖИТТЯ ЧОЛОВІЧОГО I ЖІНОЧОГО НАСЕЛЕННЯ В СУЧАСНОМУ СУСПІЛЬСТВІ НА ОСНОВІ SF-36
}

\section{Тетяна Круцевич ${ }^{1 \mathrm{ABCD}}$, Сергій Трачук ${ }^{1 \mathrm{ABCD}}$, Оксана Іванік ${ }^{1 \mathrm{ABCD}}$, Наталья Пангелова $^{2 A B C D}$, Марія Бричук ${ }^{1 A B C D}$, Галина Кедрич ${ }^{3 A B C D}$}

\author{
${ }^{1}$ Національний університет фізичного виховання та спорту України \\ ${ }^{2}$ Університет Григорія Сковороди в Переяславі \\ ${ }^{3}$ Кременецька обласна гуманітарно-педагогічна академія імені тараса Шевченка
}

Авторський вклад: А - дизайн дослідження; В - збір даних; C - статаналіз; D - підготовка рукопису; Е - збір коштів

Реферат. Стаття: 8 с., 2 табл., 3 рис. 30 джерел.

Мета дослідження - проаналізувати головні чинники якості життя чоловічого і жіночого населення в сучасному українському суспільстві.

Матеріали та методи. У соціологічних дослідженнях брали участь 482 чоловіків і жінок 20-60 років. Для вирішення поставлених завдань використовувалися наступні методи дослідження: аналіз та обробка спеціальної літератури та даних з Інтернету; педагогічне спостереження; анкетування (опитувальник SF-36), методи математичної статистики.

Результати. Результати власних досліджень свідчать, що чоловіче населення мало кращі показники якості жит- тя за всіма шкалами опитувальника SF-36 в порівнянні 3 жіночим $(\mathrm{p}<0,05)$. Показники якості життя вище середніх мали респонденти у віці 20-29 років за шкалами фізичного, рольового фізичного функціонування; больовий синдром в цій віковій групі не чинив істотного впливу на якість життя. Загальний стан здоров'я оцінювався вище середнього рівня респондентами 20-29 років і $30-39$ років незалежно від статі, для них були характерні високі показники шкал соціальної активності та життєздатності.

Висновки. Встановлено, що показник «загальний стан здоров'я» $€$ системоутворюючим чинником якості життя для чоловічого і жіночого контингенту за кількістю коре- 
ляційних зв'язків. Отримані результати дозволили визначити доцільність та швидкість впровадження превентивних заходів для чоловіків і жінок в залежності від контенту визначених шкал. Зниження показника $(\mathrm{GH})$ загального стану здоров'я у чоловіків і жінок після 50 -ти років значно впливає на складові якості їх життя, про що свідчить велика кількість значущих коефіцієнтів кореляції. У жінок після 50 ти років відмічається різке зниження показника RP (рольове функціонування, обумовлене фізичним станом) до 46 балів, життєвої активності (VT) до 50 балів, рольо- вого функціонування (обумовленого емоційним станом) (RE) до 53 балів. У чоловіків в цьому віці рольове функціонування підвищується до 90 балів, а соціальне функціонування (SF) до 89 балів, що може свідчити про нерівномірне розподілення сімейних і соціальних функцій в житті осіб різної статті, перевантаження жінок побутовими справами, що заважає їм активно проводити вільний час, впливає на емоційний стан.

Ключові слова: якість життя, фізична активність, здоров’я, особи зрілого віку.

\section{Information about the authors:}

Krutsevich T.: tmfv@ukr.net; https://orcid.org/0000-0002-4901-6148; Department of Theory and Methods of Physical Education, National University of Ukraine on Physical Education and Sport, Fizkultury St, 1, Kyiv, 03150, Ukraine.

Trachuk S.: trachuk_sergey@i.ua; https://orcid.org/0000-0002-5580-0510; Department of Theory and Methods of Physical Education, National University of Ukraine on Physical Education and Sport, Fizkultury St, 1, Kyiv, 03150, Ukraine.

Ivanik O.: tmfv@ukr.net; https://orcid.org/0000-0002-9458-7695; Department of Theory and Methods of Physical Education, National University of Ukraine on Physical Education and Sport, Fizkultury St, 1, Kyiv, 03150, Ukraine.

Panhelova N.: kafedra.tmfvis@ukr.net; https://orcid.org/0000-0002-4846-3907; Department of Theory and Methods of Physical Education and Sports, Hryhorii Skovoroda University in Pereiaslav, Sukhomlynskoho St, 30, Pereiaslav, 08401, Kyiv region, Ukraine.

Brychuk M.: maxa.brychuk@gmail.com; https://orcid.org/0000-0002-9094-0527; Department of Theory and Methods of Physical Education, National University of Ukraine on Physical Education and Sport, Fizkultury St, 1, Kyiv, 03150, Ukraine.

Kedrych H.: kedruch90@gmail.com; https://orcid.org/0000-0002-1333-1226; Department of Sports Games and Tourism, Taras Shevchenko Regional Humanitarian Pedagogical Academy in Kremenets, Litseina St, 1, Kremenets, Ternopil region, 47003, Ukraine.

Cite this article as: Krutsevich, T., Trachuk, S., Ivanik, O., Panhelova, N., Brychuk, M., \& Kedrych, H. (2021). Assessment of a Healthy Lifestyle and Quality of Life of Men and Women in Modern Society Based on Sf 36. Teoriâ ta Metodika Fizičnogo Vihovannâ, 21(3), 211-218. https://doi.org/10.17309/tmfv.2021.3.04

Received: 01.07.2021. Accepted: 12.08.2021. Published: 25.09.2021

This work is licensed under a Creative Commons Attribution 4.0 International License (http://creativecommons.org/licenses/by/4.0). 